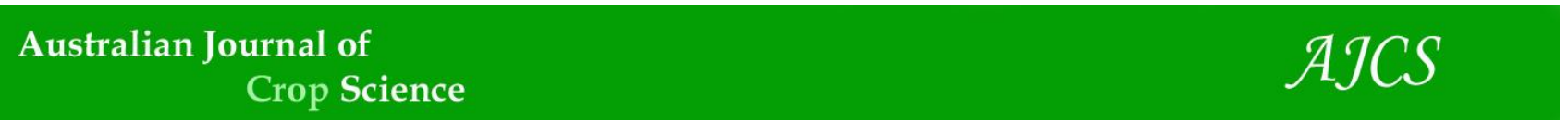

AJCS 14(10):1555-1562 (2020)

ISSN:1835-2707

doi: 10.21475/ajcs.20.14.10.p1769

\title{
Cropping system to produce lettuce in autumn season at different elevations
}

\author{
Luiz Fernando Favarato', Maurício José Fornazier², Frederico Jacob Eutrópio ${ }^{3}$, Rogério Carvalho Guarçoni ${ }^{4}$, \\ Lidiane Mendes ${ }^{5}$
}

${ }^{1}$ Research Center, Development and Innovation Serrano, Instituto Capixaba de Pesquisa, Assistência Técnica e Extensão Rural, Br 262, Km 94, 29375-000 Venda Nova do Imigrante, Espírito Santo, Brazil

${ }^{2}$ Research Center, Development and Innovation Serrano, Instituto Capixaba de Pesquisa, Assistência Técnica e Extensão Rural, Br 262, Km 94, 29375-000 Venda Nova do Imigrante, Espírito Santo, Brazil mauriciofornazier@gmail.com.

${ }^{3}$ Multivix College Vila Velha, Rua Sete de Setembro - Centro de Vila Velha, Vila Velha - ES, 29100-301, Espírito Santo, Brazil

${ }^{4}$ Research Center, Development and Innovation Serrano, Instituto Capixaba de Pesquisa, Assistência Técnica e

Extensão Rural, Br 262, Km 94, 29375-000 Venda Nova do Imigrante, Espírito Santo, Brazil

${ }^{5}$ Food Science and Technology, Instituto Federal do Espírito Santo, Campus Venda Nova do Imigrante, 29375-000

Venda Nova do Imigrante, Espírito Santo, Brazil

*Corresponding author: Iffavarato@gmail.com

\begin{abstract}
Lettuce is an annual herbaceous plant, native to the mild climate regions of the northern Mediterranean. Lettuce varieties can likely be developed well in mild temperatures, but the cold and frosty winds of the autumn/winter season may damage the leaves. Their cultivation under low tunnels is an alternative to reduce this problem. This study was carried out with the aim of evaluating the influence of different cropping systems on the productive performance of lettuce in the autumn/winter cropping season. The experiments were installed following a split plot scheme with three cropping systems: (i) Open field with black polyethylene mulching (BPM); (ii) low tunnel (LT); (iii) Open field cropping (OFC) system without BPM. Three lettuce varieties of different groups were used in the subplots, with a total of nine treatments. The experimental design was of randomized blocks with four replications, at two altitudes (700 and $950 \mathrm{~m}$ ). The number of leaves per plant, stem length, head diameter, fresh and dry matter mass per plant, leaf area index, and specific leaf area were evaluated. LT should be used for lettuce cultivation at an altitude of 950 $\mathrm{m}$, as it provided higher productive performance in the autumn season. The use of the low tunnel provided for the production of lettuce plants with thinner leaves and better visual appearance, at an altitude of $700 \mathrm{~m}$.
\end{abstract}

Keywords: low tunnel; mulching; varieties; lactuca sativa; polyethylene.

Abbreviations: BPM_black polyethylene mulching; LT_low tunnel; OFC_open field cropping system without black polyethylene mulching; LAI_leaf area index; PC_principal components

Introduction

Protected environments have been used for plant cultivation and have become increasingly necessary in agriculture to obtain better quality "in natura" foods.

This type of crop system has shown great development in its cultivated area in Brazil, mainly for vegetables and flowers (Gualberto et al., 2009; Silva et al., 2014). Commercial cultivation of vegetables in protected environments is a consolidated activity, mainly in the vicinity of a large urban population. These environments have indicated the capacity for high production in small areas and can supply the high demand for food quality and quantity (Fao, 2018).

Worldwide, including in Brazil, lettuce, cucumber, sweet pepper, and tomatoes are among the most cultivated vegetables in protected environments. However, lettuce is the most widespread of the leafy vegetables and is grown almost everywhere in the world. Its worldwide planted area was 1.2 million ha with a production of 26.8 million tons in
2017 (Fao, 2017). This is the sixth most valuable vegetable in economic importance, and the eighth most produced in Brazil. In addition to the economic and food value, its cultivation has a great social importance because of the large number of stakeholders involved in its production and marketing chain (Prohort, 2019).

Despite its cultivation in all Brazilian regions, its cultivated area is restricted because of its sensitivity to higher or lower temperature, air humidity, and rainfall conditions (Hatfield and Prueger, 2015), such as, temperatures below $10^{\circ} \mathrm{C}$ and longer periods of rainfall. On the other hand, temperatures above $20^{\circ} \mathrm{C}$ and intense solar radiation induce their early floral tassel issue, and cause burning of the edges of the outer leaves, induce formation of compact heads, and contribute to the occurrence of calcium deficiency (e.g., tipburn) (llić et al., 2017). 
The productive performance was always found to be higher for lettuce cultivation in protected environments than in open fields, due to temperature, relative humidity, solar radiation, and wind speed is more appropriate in the protected environment (Golzar et al., 2018). However, the success of this system depends on the choice of the variety to be used, which has to be accurate, as lettuce depends on the interaction of genotype $x$ environment (Kerbiriou et al., 2016). Moreover, each region of lettuce production has a better adaptation to regional climatic conditions, such as, temperature, and photoperiod required for its development (Graamans et al., 2018).

Due to the importance of vegetables in our daily food intake and the cost of their production and high economic value, particularly in the off-season, research is needed on their development and/or to adopt technologies at regional levels, with the aim of increasing yield and reducing risks. Thus, this study aims to evaluate the influence of different cropping systems on the productive performance of lettuce cultivation in the autumn/winter cropping season, at different altitudes.

\section{Results and discussion}

\section{Fresh and dry matter mass}

The cultivation systems in LT using BPM, provided the greatest fresh matter mass for the varieties of 'Vanda' (leaf lettuce), 'Regina' (butterhead), and 'Lucy Brown' (iceberg lettuce), when compared to OFC. It was necessary to use LT to obtain the best performance of the American variety, where a mean weight of $\sim 540$ g per plant was obtained. However, in the experiment at $950 \mathrm{~m}$, only the American variety showed a difference between the cultivation systems, and the largest weights ( $>500 \mathrm{~g}$ per plant) were obtained using LT (Figure 3). Lettuce varieties of the American group had the potential for a production of up to 550 g per plant at higher altitudes (Cardoso et al., 2018), which could reduce these values to $400 \mathrm{~g}$ per plant at altitudes of $700 \mathrm{~m}$, similar to that used in the second experiment (Maggi et al., 2006). Thus, it could be assumed that the experiments might express a high productive potential for the cultivars tested. The higher mass production of fresh matter obtained in the LT system may be related to the increase of the nutrient absorption due to the stimulation of root activity, maintenance at adequate levels of humidity, and reduction of the fluctuations in daily temperature (Kosterna et al., 2014), as both environments used had the soil covered.

Similarly, Meneses et al. (2016) and Tosta et al. (2010) verified a significant increase in the fresh matter mass of lettuce using different soil coverings with BPM and straw. The highest yields were obtained with soil cover using BPM in the OFC system. There was no difference between the cropping systems when the dry matter mass was evaluated (Figure 4) within each variety in the experiment conducted at $700 \mathrm{~m}$. However, the yield of curly lettuce was higher in the OFC system in the experiment at $950 \mathrm{~m}$.

\section{Number of leaves}

Cropping systems influenced the number of leaves in lettuce varieties, smooth and American, at both altitudes used (Figure 5). For both, there was an increase (17\%) in the number of leaves in the LT system when compared to OFC. Smooth lettuce showed great potential for leaf production at both altitudes, with $\sim 20$ leaves, greater than the American variety. Lettuce cultivated in a protected environment tends to show a greater number of leaves than that grown in the OFC (Brzezinski et al., 2017; Gent, 2017).

The increase in the number of leaves may be related to the highest number of degree-days in a protected environment, due to lower thermal variation (Reyes et al., 2017). The more constant temperature in this environment may have stimulated and increased the speed of the biochemical reactions and the sap flow, promoting greater plant growth (Bisbis et al., 2018).

\section{Head diameter and stem length}

The head diameter and fresh matter mass showed the highest vigor and best commercial appearance of lettuce plants grown under a protected environment. All varieties grown under LT had head diameter $~ 25 \%$ higher than those grown under OFC at $700 \mathrm{~m}$. Only the American variety showed difference at $950 \mathrm{~m}$, with higher values observed in LT (Figure 6).

Production of American lettuce heads was found to be larger ( 14\%) under LT than in OFC (Brzezinski et al., 2017), similar to that observed in the present study for this same lettuce group at $950 \mathrm{~m}$ (Figure 6). The difference observed may be a function of the thermal amplitude of the different cropping systems, and this effect may have been minimized for the plants produced in LT. In conditions of drastic oscillations in air temperature, as can occur in the OFC, there is a reduction of the culture cycle, and consequently, a smaller head diameter may be observed (Silva et al., 2017).

The influence of the cultivation environments on stem length at $950 \mathrm{~m}$ was observed, and higher values for the three lettuce varieties tested in LT were obtained (Figure 7). However, all varieties were within the marketing standard. Stems up to $6.0 \mathrm{~cm}$ was the most adequate, however, stems up to $9.0 \mathrm{~cm}$ could be acceptable (Yuri et al., 2004). The largest stem length observed could be indicative of the highest sensitivity to early tillage, an undesirable trait for lettuce.

The American variety showed a lower stem length $(3.1 \mathrm{~cm}$ to $5.3 \mathrm{~cm}$ ), independent of the cropping environment. Similar values were found by Yuri et al. (2002), emphasizing that this characteristic is of great importance, mainly when the lettuce is destined to reach the processing industry. Moreover, it can impair the compactness of the head and negatively influence the final quality of the product. The stem length should be greatly reduced, with the aim to lower processing losses.

\section{Leaf area index and specific area}

The leaf area index (LAI) of the smooth lettuce variety at 700 $\mathrm{m}$ asl, and the smooth and American varieties at $950 \mathrm{~m}$ were influenced by the different cropping systems (Figure 8). A higher leaf area index value was observed in the smooth cultivar in LT at $700 \mathrm{~m}$, indicating a larger leaf expansion, and this may be related to the reduction in the incident solar radiation provided by this environment (Gent, 2017).

A higher leaf area index was found in the BPM and OFC environments, in the smooth variety, and in the BPM to the American cultivar at $950 \mathrm{~m}$. Light is one of the main factors 
Table 1. Principal components, their respective eigenvalues, and simple and cumulative percentages of the total variance at altitudes of $700 \mathrm{~m}$ and $950 \mathrm{~m}$.

\begin{tabular}{lllll}
\cline { 2 - 5 } & $700 \mathrm{~m}$ & & $950 \mathrm{~m}$ & \\
\hline Principal components & PC1 & PC2 & PC1 & PC2 \\
Eigenvalues & 8.79 & 0.15 & 8.85 & 0.09 \\
Simple percentage (\%) & 97.76 & 1.63 & 98.35 & 1.08 \\
Accumulated percentage (\%) & 97.76 & 99.39 & 98.35 & 99.43 \\
\hline
\end{tabular}

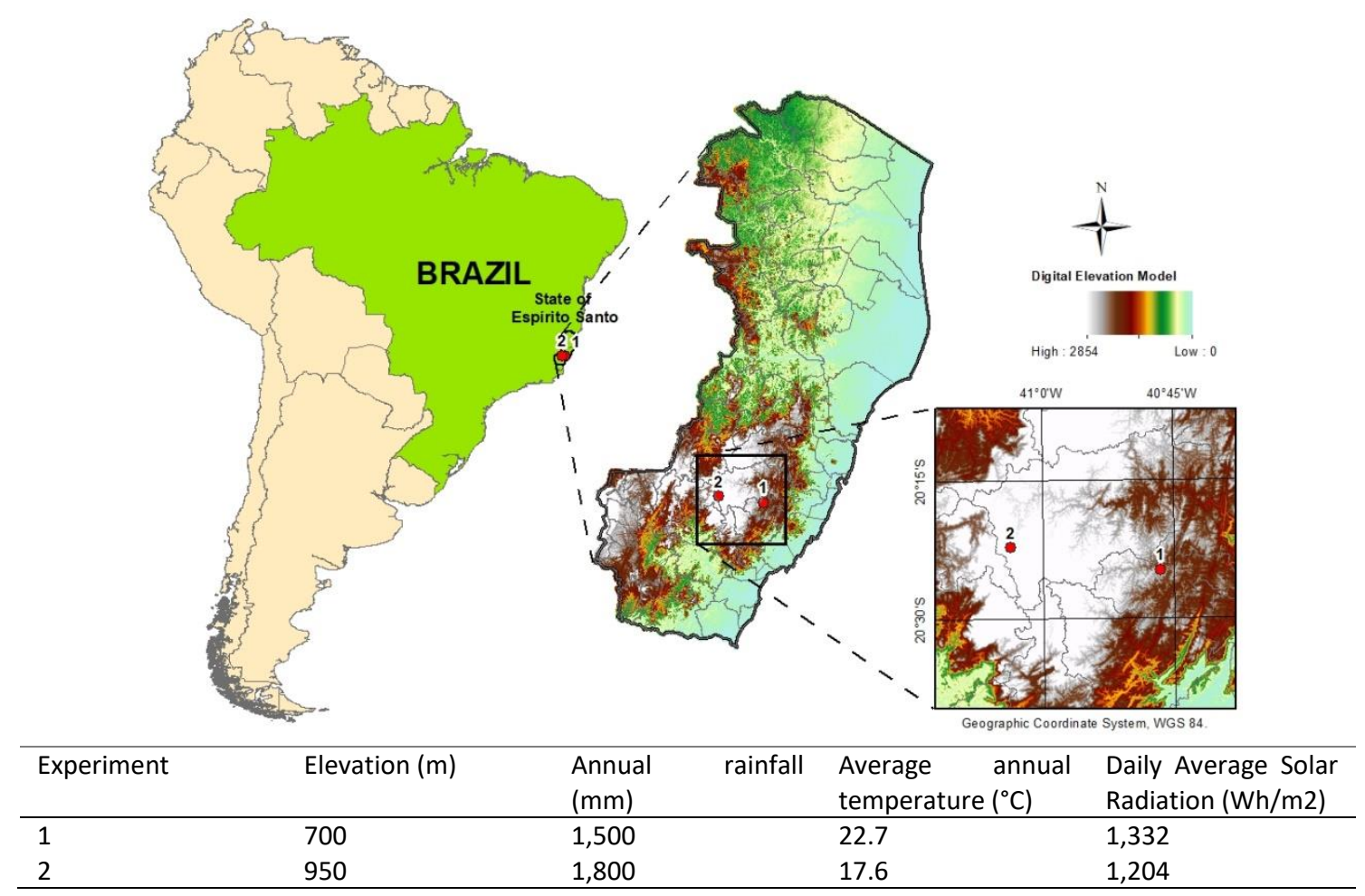

Fig 1. Location of the study area, elevation, average annual temperature and incidence of solar radiation for the two experiments.
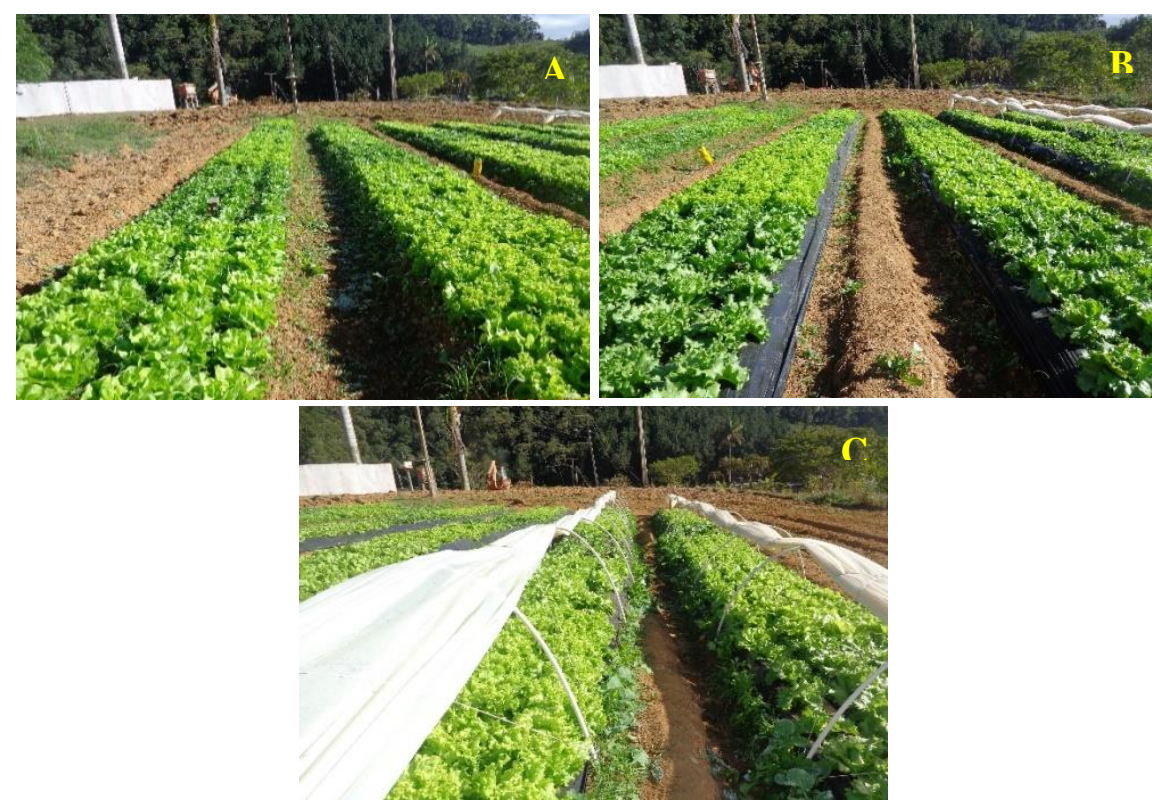

Fig 2. Performance of lettuce at Open field cropping system (OFC) with (A) without black polyethylene mulching (BPM) (B) and low tunnel (C). 


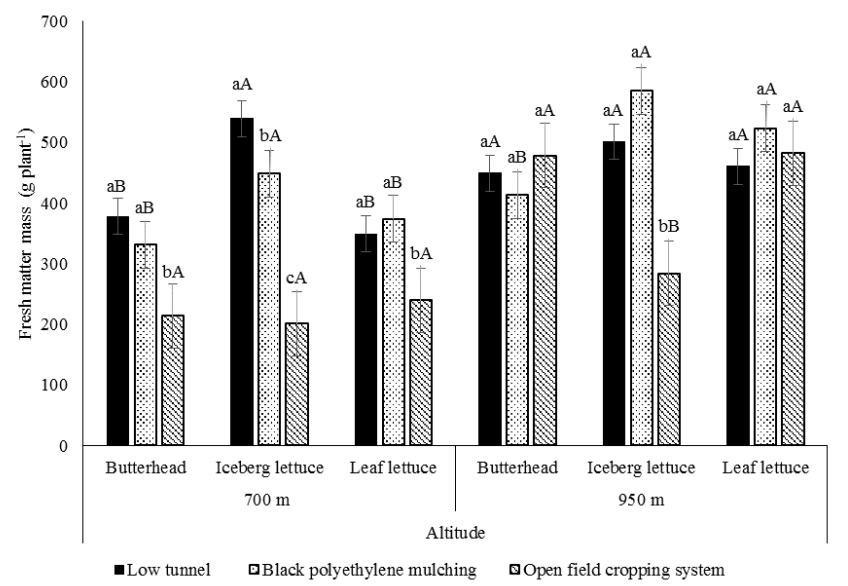

Fig 3. Mean values of fresh matter mass per plants of lettuce varieties grown in different cropping systems at two altitudes. Bars followed by the same lowercase letters do not show significant differences between cropping systems within each variety. Bars followed by the same capital letters did not show significant differences among varieties within the same cropping system ( $p \leq$ $0.05)$.

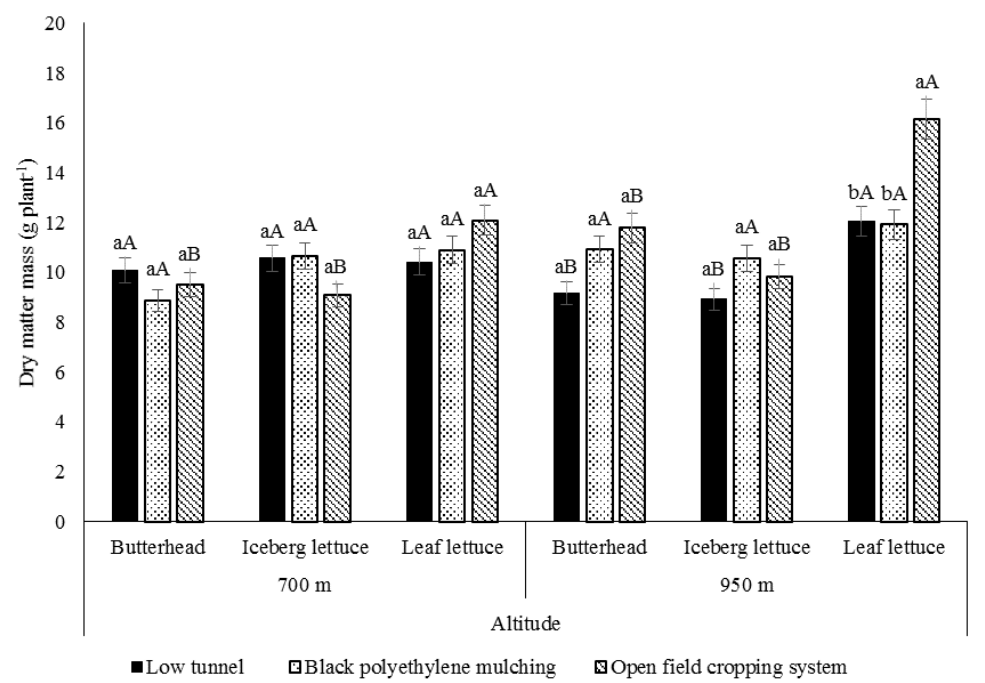

Fig 4. Mean values of dry matter mass per plant of lettuce varieties grown in different cropping systems at two altitudes. Bars followed by the same lowercase letters do not show significant differences between cropping systems within each variety. Bars followed by the same capital letters did not show significant differences among varieties within the same cropping system ( $p \leq$ $0.05)$.

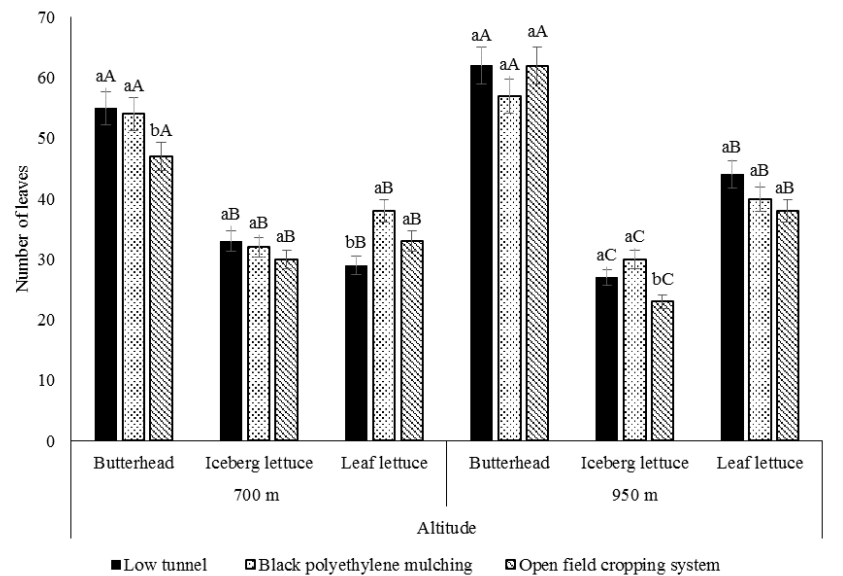

Fig 5. Mean values of the number of leaves per plant of lettuce varieties grown in different cropping systems at two altitudes. Bars followed by the same lowercase letters do not show significant differences between cropping systems within each variety. Bars followed by the same capital letters did not show significant differences among varieties within the same cropping system ( $p \leq$ 0.05). 


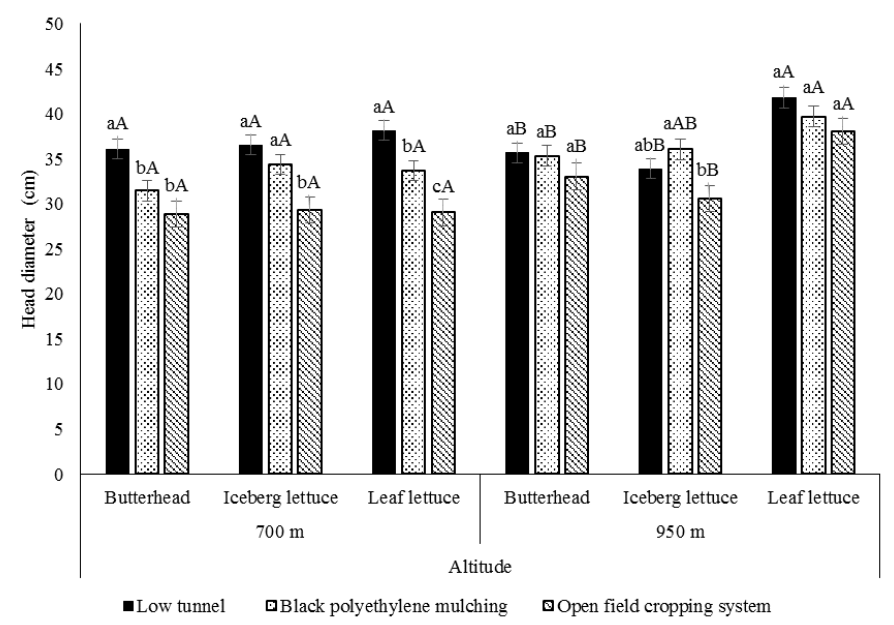

Fig 6. Mean values of plant head diameter of lettuce varieties grown in different cropping systems at two altitudes. Bars followed by the same lowercase letters do not show significant differences between cropping systems within each variety. Bars followed by the same capital letters did not show significant differences among varieties within the same cropping system $(p \leq 0.05)$.

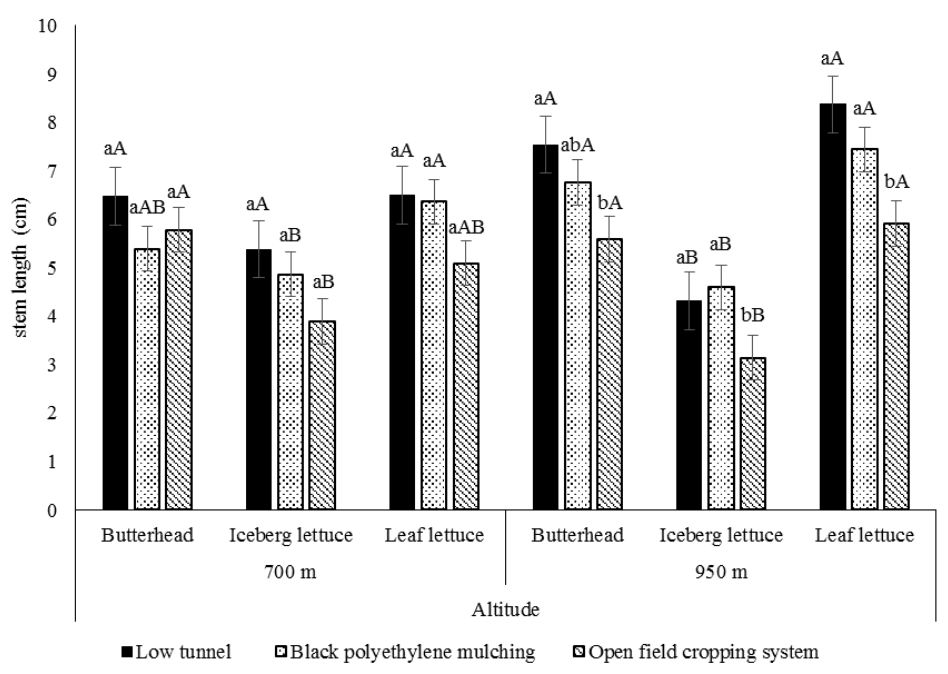

Fig 7. Mean values of stem length of lettuce varieties grown in different cropping systems at two altitudes. Bars followed by the same lowercase letters do not show significant differences between cropping systems within each variety. Bars followed by the same capital letters did not show significant differences among varieties within the same cropping system $(p \leq 0.05)$.

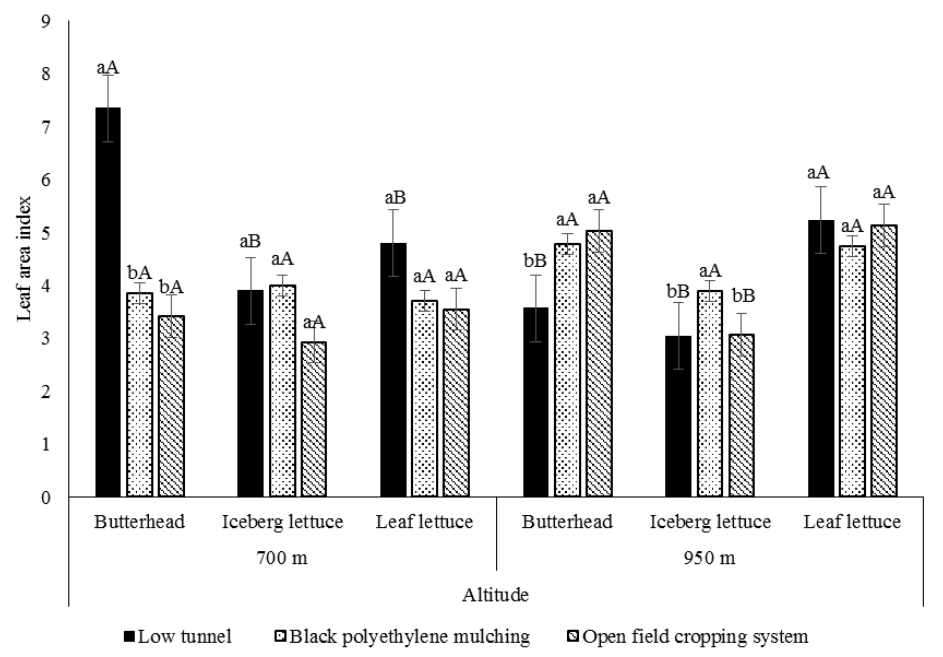

Fig 8. Mean values of leaf area index of lettuce varieties grown in different cropping systems at two altitudes. Bars followed by the same lowercase letters do not show significant differences between cropping systems within each variety. Bars followed by the same capital letters did not show significant differences among varieties within the same cropping system $(p \leq 0.05)$. 


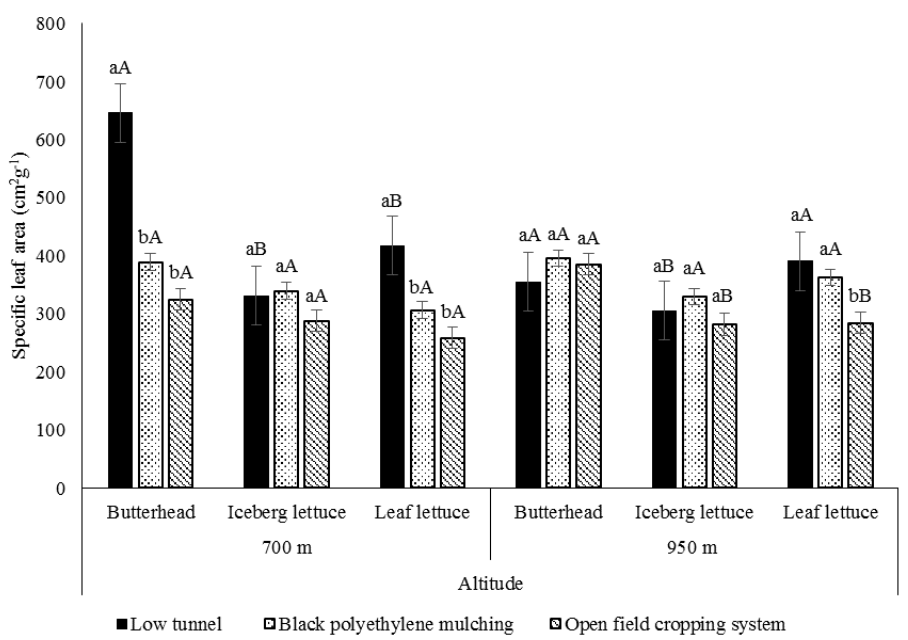

Fig 9. Mean values of specific leaf area of lettuce varieties grown in different cropping systems at two altitudes. Bars followed by the same lowercase letters do not show significant differences between cropping systems within each variety. Bars followed by the same capital letters did not show significant differences among varieties within the same cropping system $(p \leq 0.05)$.

A

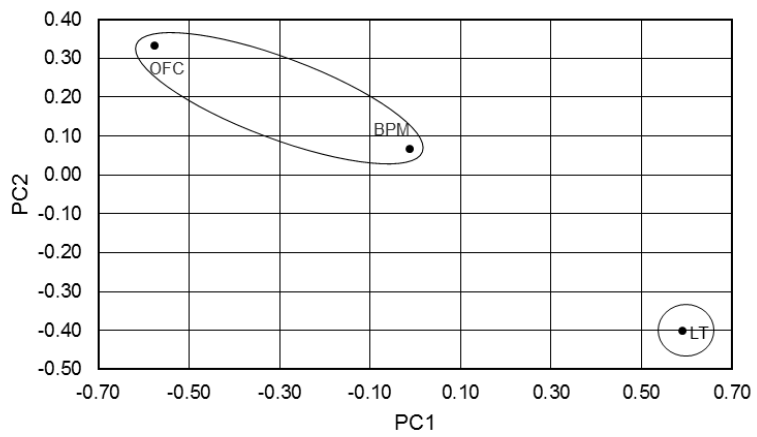

B

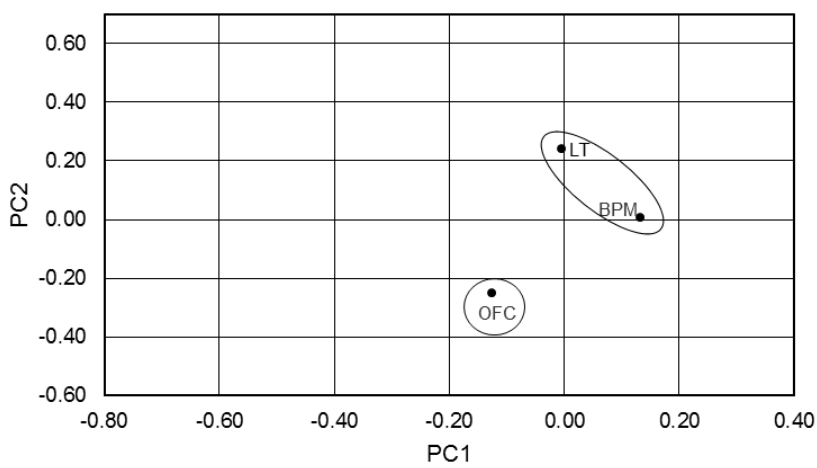

Fig 10. Dispersion diagram in relation to the first two main components of the lower tunnel (LT), black plastic mulching (BPM) and open field cropping (OFC) environments, at altitudes of $700 \mathrm{~m} \mathrm{(A)}$ and $950 \mathrm{~m}$ (B).

limiting plant development and leaf is the main photosynthetic organ of plants, and light directly interferes with its growth (Taiz and Zeiger, 2010).

Thus, environments with a lower degree of shading $(950 \mathrm{~m})$ provided a more favorable condition for lettuce plants to express their genetic potential. The LT provided a specific leaf area $50 \%$ higher than OFC for smooth and curly varieties at $700 \mathrm{~m}$ (Figure 9). In this environment the leaves are thinner, a fact attributed mainly to the higher relative air humidity found in the greenhouse during the nychthemeron (twenty-four hours or a day and a night) (Tibbits and
Bottemberg, 1976), in addition to the effect of lower availability of incident solar radiation (Gent, 2017).

Leaves that have had their cellular expansion under conditions of low availability of solar radiation are thinner and have a larger leaf surface than those that have expanded under conditions of high availability of solar radiation (Charles-edwards, 1986). This feature may favor the visual presentation of lettuce, but may be a negative characteristic for resistance to transportation and post harvest conservation. The management of air humidity, and mainly the soil inside protected environments, may be of extreme importance in the pre-harvest period, as it should 
aim to increase the resistance of leaves for transport (Favarato et al, 2017).

\section{Principal components}

The analysis of the main components pointed out that LT provided better productive performance for lettuce cultivation than OFC, at $700 \mathrm{~m}$ (Figure 10A). The BPM and OFC environments formed a separate group from the LT group, and the two components (PC1 and PC2) absorbed $99.39 \%$ of the variation from the original characteristics (Table 1).

This fact was probably due to the favorable microclimate that modified the temperature and relative air humidity, solar radiation, and wind speed, influencing the development and growth of lettuce inside LT (Rebouças et al., 2015) in the autumn/winter crop season. The cultivation of lettuce at $950 \mathrm{~m}$ was favored by the use of LT and BPM, as observed in the principal component analysis (Figure 10B). LT and BPM formed a separate group from the OFC and these two components absorbed $99.43 \%$ of the variation from the original characteristics (Table 1 ). This may be related to the higher air temperature that LT and BPM tend to induce. The BPM has physical characteristics that allow the absorption and irradiation of a greater amount of heat than the uncovered soil. LT has the ability to promote the greenhouse effect and raise the temperature of the environment by modifying the microclimate, altering temperature, and relative air humidity, and this influences the development and growth of lettuce.

\section{Materials and methods}

\section{Location and treatments}

The experiments were carried out at two different altitudes (700 and $950 \mathrm{~m}$ ) in the highlands of the state of Espírito Santo, Brazil, representing the main lettuce-producing regions of this Brazilian state (Figure 1 ).

The planting was initialized in both experiments in July 2016, in a split-plot scheme with three cropping systems in the plots and three lettuce varieties in the subplots, totaling nine treatments, arranged in a randomized complete block design with four replicates.

The open field cropping system (OFC) with and without mulching with $25 \mu$ black polyethylene (BPM) and low tunnel systems (LT) (Figure 2) were compared in the plots. 'Vanda' (leaf lettuce), 'Lucy Brown' (iceberg lettuce), and 'Regina' (butterhead), were the three varieties of lettuce evaluated.

\section{Seedling production and cultures}

Seedlings were produced in polypropylene trays with 288 cells, using a substrate based on pine bark. Transplanting to the field was done when the seedling had three to five definitive leaves. The experimental plots consisted of beds $1.2 \mathrm{~m}$ wide, $3 \mathrm{~m}$ long, and $0.3 \mathrm{~m}$ high, with four plant lines, with a space of $0.3 \times 0.3 \mathrm{~m}$ between plants. A total of forty plants were used per plot, and 12 of these plants from the two central rows were used for the evaluation procedures. Beds were prepared using a rotating hoe and $6.0 \mathrm{~g} \mathrm{~N}, 21,0 \mathrm{~g}$ $\mathrm{P}_{2} \mathrm{O}_{5}, 12.0 \mathrm{~g} \mathrm{~K}_{2} \mathrm{O} \mathrm{m} \mathrm{m}^{-2}+1.5 \mathrm{~kg} \mathrm{~m}^{-2}$ of the organic fertilizer Visafertil were used. The BPM used was drilled in the spacing previously determined and was placed just after the placement of the drip irrigation system in the plots that received this luxury.

The LT was supported by PVC tubes (3/4"), covered with transparent polyethylene film of low density $(150 \mu)$ and placed just after planting the seedlings. One drip tube/row was used, and irrigation was done daily. Three complementary fertilizations were done 10, 20, and 30 days after planting, using drip fertigation, with $6.75 \mathrm{~g} \mathrm{~N} \mathrm{~m}^{-2}$ in each one.

\section{Evaluations and statistical analysis}

Evaluation of the development indices of lettuce plants was carried out 46 days after planting, when those 12 plants from the central rows of the plot were harvested. Harvesting was performed from 8 a.m. to 10 a.m. to obtain plants with the same potential hydration.

The number of leaves per plant ( $\geq 15 \mathrm{~mm}$ in length), stem length $(\mathrm{mm})$, head diameter $(\mathrm{mm})$, and leaf area index (LAI) were measured. LAI was determined by the ratio between leaf area $\left(\mathrm{mm}^{2}\right)$ and surface area $\left(\mathrm{mm}^{2}\right)$ projected on the soil. Also, the specific leaf area, obtained by the ratio between leaf area $\left(\mathrm{mm}^{2}\right)$ and dry matter mass $(\mathrm{g})$ per plant was determined. Leaf area determination was performed using the leaf disc method (Fernandes 2000).

The mass of the fresh matter $(\mathrm{g})$ and dry matter $(\mathrm{g})$ were evaluated for the productive performance of the varieties, and the dry mass was obtained by drying the plants in an oven with forced circulation, at $65^{\circ} \mathrm{C}$, until reaching constant weight.

Data were submitted to analysis of variance and the means were compared by the Tukey test $(p=0.05)$. The principal component analyses were performed aiming to group the treatments, using visual exams in graphic dispersions. Cumulative variability above $70 \%$ was considered adequate for its accomplishment. The SAEG program (RIBEIRO JÚNIOR and MELO, 2008) was used for statistical analyses.

\section{Conclusion}

Low tunnel must be used to obtain higher productivity in the autumn/winter lettuce crop season at an altitude of $950 \mathrm{~m}$. Lettuce quality has improved in low tunnel cultivation at an altitude of $700 \mathrm{~m}$, showing plants with more tender leaves and better visual appearance. Smooth, curly, and American varieties of lettuce grown under low tunnel and black polyethylene mulching have better productive performance than those in the conventional system used by producers.

\section{Acknowledgments}

The authors would like to thank,

The Fundação de Amparo à Pesquisa e Inovação do Espírito Santo (FAPES) for financial support and The City Hall de Marechal Floriano for their partnership in conducting the study.

\section{References}

Andriolo JL (1999) Fisiologia das culturas protegidas. UFSM, Santa Maria Rio Grande do Sul Brasil.

Bisbis MB, Gruda N, Blanke M (2018) Potential impacts of climate change on vegetable production and product quality - A review. J Clean Prod. 170: 1602-1620. 
Brzezinski CR, Abati A, Geller A, Werner F, Zucareli C (2017) Produção de cultivares de alface americana sob dois sistemas de cultivo. Revista Ceres. 64: 83-89.

Cardoso SS, Guimarães MA, Lemos Neto HS, Jesus Tello JPJ, Vale JC (2018) Morphological and productive aspects of lettuce in low altitude and latitude. Rev Ciênc Agron. 49: 644-652.

Charles-Edwards DA, Doley D, Rimmington GM. Modelling plant growth and development. North Ryde: Academic Press, $235 \mathrm{p}$.

Espírito Santo (State) (1999). Zonas naturais do espírito santo: uma regionalização do estado, das microrregiões e dos municípios/ Secretaria de Estado do Planejamento. Vitória: SEPLAN, $101 \mathrm{p}$.

Golzar F, Heeren N, Hellweg S, Roshandel, R (2018) A novel integrated framework to evaluate greenhouse energy demand and crop yield production. Renew Sust Energ Rev. 96: 487-501.

Fao - Food and Agriculture Organization of the United Nations. Rome (2017). Disponível em: <http://faostat.fao.org>. Access in: 15 nov. 2018.

Fao - Food and Agriculture Organization of the United Nations (2018). The State of Food and Agriculture. Migration, agriculture and rural development. Rome. Licence: CC BY-NC-SA 3.0 IGO.

Favarato LF, Guarçoni RC, Siqueira APO (2017) Produção de alface de primavera/verão sob diferentes sistemas de cultivo. Rev Cient Intelletto. 2: 16-28.

Fernandes PD (2000) Análise de crescimento e desenvolvimento vegetal. UFPB, Campina Grande Paraiba Brasil.

Gent MPN (2017) Factors Affecting Relative Growth Rate of Lettuce and Spinach in Hydroponics in a Greenhouse. HortSci. 52: 1742-1747.

Graamans L, Baeza E, Dobbelsteen A, Tsafaras I, Stanghellini C (2018) Plant factories versus greenhouses: Comparison of resource use efficiency. Agr Syst. 160: 31-43.

Gualberto R, Oliveira PSR, Guimarães AM (2009) Adaptabilidade e estabilidade fenotípica de cultivares de alface do grupo crespa em cultivo hidropônico. Hort Brasileira. 27: 7-11.

Hatfield JL, Prueger JH (2015) Temperature extremes: Effect on plant growth and development. Weather Clim Extrem. 10: 4-10.

Ilić,SZ, Milenković L, Dimitrijević A, Stanojević L, Cvetković D, Kevrešan Ž, Fallik E, Mastilović J (2017) Light modification by color nets improve quality of lettuce from summer production. Sci Hort. 226: 389-397.

Kosterna E (2014) Soil mulching with straw in broccoli cultivation for early harvest. J Environ Eng.15:100-107.
Kerbiriou PJ, Maliepaard CA, Stomph TJ, Koper M, Froissart D, Roobeek I, Van Bueren ETL, Struik PC (2016) Genetic Control of Water and Nitrate Capture and Their Use Efficiency in Lettuce (Lactuca sativa L.). Front Plant Sci. 7: 343.

Meneses NB, Moreira MA, Souza IM de, Bianchini FG (2016) Crescimento e produtividade de alface sob diferentes tipos de cobertura do solo. Rev Agro@mbiente On-line. 10: 123129.

Prohort. Programa brasileiro de modernização do mercado hortigrangeiro. Disponível em: <http://dw.prohort.conab.gov.br/pentaho/Prohort>. Access in: 25 mar. 2019.

Rebouças PM, Dias IF, Alves MA, Barbosa Filho JAD (2015) Radiação solar e temperatura do ar em ambiente protegido. Rev Agrogeoambiental. 7: 115-125.

Reyes MA, Álvarez-Herrera JG, Fraile-Robayo RD, ÁlvarezHerrera OF, Fraile-Robayo AL (2017) Evaluation of the growth and quality of lettuce (Lactuca sativa L.) in a closed recirculating hydroponic system. Agron Colomb. 35: 216222.

Silva AFT, Avelino RC, Brito LPS, Anjos JCR, Silva Júnior JV, Cavalcante MZB (2017) Growth and yield of lettuce cultivars under organic fertilization and different environments. Com Sci. 8: 265-274.

Silva BA, Silva AR, Pagiuca LG (2014) Cultivo Protegido: Em busca de mais eficiência produtiva. Rev Tec Hortifruti Brasil. 1: 10-18.

Taiz L, Zeiger E (2010) Plant Physiology, Fifth Edition. Sinauer Associates. Sunderland USA.

Tibbits TW, Bottemberg G. (1976) Growth of lettuce under controlled humidity levels. J Am Soc Hortic Sci. 101: 70-73.

Tosta PAF, Mendonça V, Tosta MS, Machado JR, Tosta JS, Medeiros LF (2010) Utilização de cobertura do solo no cultivo de alface "Babá de Verão" em Cassilâdia (MS). Rev Bras Cienc Agrária. 5: 85-89.

Yuri JE, Souza RJ de, Freitas SAC de, Rodrigues Júnior JC, Mota JH (2002) Comportamento de cultivares de alface tipo americana em Boa Esperança. Hortic Bras. 20: 229232.

Yuri JE, Resende GM, Mota JH, Souza RJ, Freitas SAC, Rodrigues Junior JC (2004) Comportamento de cultivares de alface americana em Santana da Vargem. Hortic Bras. 22: 249-252. 